Reluctant Interveners 


\section{Genocide, Political Violence, Human Rights Series}

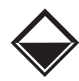

Edited by Alexander Laban Hinton, Stephen Eric Bronner, and Nela Navarro

Nanci Adler, ed., Understanding the Age of Transitional Justice: Crimes, Courts, Commissions, and Chronicling

Alan W. Clarke, Rendition to Torture

Alison Crosby and M. Brinton Lykes, Beyond Repair?: Mayan Women's Protagonism in the Aftermath of Genocidal Harm

Lawrence Davidson, Cultural Genocide

Daniel Feierstein, Genocide as Social Practice: Reorganizing Society under the Nazis and Argentina's Military Juntas

Alexander Laban Hinton, ed., Transitional Justice: Global Mechanisms and Local Realities after Genocide and Mass Violence

Alexander Laban Hinton, Thomas La Pointe, and Douglas Irvin-Erickson, eds., Hidden Genocides: Power, Knowledge, Memory

Douglas A. Kammen, Three Centuries of Conflict in East Timor

Eyal Mayroz, Reluctant Interveners: America's Failed Responses to Genocide from Bosnia to Darfur

Walter Richmond, The Circassian Genocide

S. Garnett Rusell, Becoming Rwandan: Education, Reconciliation, and the Making of a Post-Genocide Citizen

Victoria Sanford, Katerina Stefatos, and Cecilia M. Salvi, eds., Gender Violence in Peace and War: States of Complicity

Irina Silber, Everyday Revolutionaries: Gender, Violence, and Disillusionment in Postwar El Salvador

Samuel Totten and Rafiki Ubaldo, eds., We Cannot Forget: Interviews with Survivors of the 1994 Genocide in Rwanda

Anton Weiss-Wendt, A Rhetorical Crime: Genocide in the Geopolitical Discourse of the Cold War

Ronnie Yimsut, Facing the Khmer Rouge: A Cambodian Journey 


\title{
Reluctant Interveners
}

\author{
AMERICA'S FAILED \\ Responses to Genocide \\ FROM BOSNIA TO DARFUR
}

Eyal Mayroz 
Library of Congress Cataloging-in-Publication Data

Names: Mayroz, Eyal, 1964- author.

Title: Reluctant interveners: America's failed responses to genocide from Bosnia to Darfur / Eyal Mayroz.

Description: New Brunswick : Rutgers University Press, [2019] | Series: Genocide, political violence, human rights series | Includes bibliographical references and index.

Identifiers: LCCN 2019006129 | ISBN 9781978807037 (pbk.: alk. paper) | ISBN 9781978807044 (hc-plc)

Subjects: LCSH: Genocide intervention-Government policy-United States. | Humanitarian intervention-United States. | United States-Foreign relations-1989-

Classification: LCC JZ6369 .M378 2019 | DDC 364.15/1-dc23

LC record available at https://catalog.loc.gov/vwebv/search?searchCode $=$ LCCN \&searchArg=2019006129\&searchType $=1 \&$ permalink $=y$

A British Cataloging-in-Publication record for this book is available from the British Library.

Copyright (C) 2020 by Eyal Mayroz

All rights reserved

No part of this book may be reproduced or utilized in any form or by any means, electronic or mechanical, or by any information storage and retrieval system, without written permission from the publisher. Please contact Rutgers University Press, 106 Somerset Street, New Brunswick, NJ 08901. The only exception to this prohibition is "fair use" as defined by U.S. copyright law.

( $)$ The paper used in this publication meets the requirements of the American National Standard for Information Sciences-Permanence of Paper for Printed Library Materials, ANSI Z39.48-1992.

Www.rutgersuniversitypress.org

Manufactured in the United States of America 
To my wife Ruth and my two boys Yotam and Gitai 
